\title{
La escritura del deseo en la publicidad televisiva
}

\section{Writing of desire in television advertising}

\author{
Antía LóPEZ GómEZ \\ Universidad de Santiago de Compostela \\ antiamaria.lopez@usc.es
}

Recibido: 25-11-2011

Aceptado: 11-02-2013

\section{Resumen}

El texto publicitario de modelo dominante, paradigma de la cultura audiovisual contemporánea, puede acaso albergar un acto de deseo del cual cierto sujeto manifieste ser responsable. Situamos, así, nuestro interés en el nivel enunciativo del texto, un nivel poblado de figuras de subjetividad ocupantes de lugares que la trama define, pero uno también donde se manifiesta el roce del sujeto con el Lenguaje en tanto su deseo ha de abrirse paso ante el código. Sin embargo, es posible que dicho roce haya sido evacuado del texto, de modo que la propuesta de éste, como consecuencia, se reduzca a una mera puesta en escena, en virtud de la cual el encuentro del sujeto con el Lenguaje sea desplazado por el encuentro de una Figura con su objeto en lo imaginario.

Palabras clave: Texto, enunciación, publicidad, sujeto del inconsciente, deseo.

\begin{abstract}
The advertising text of dominant model, paradigm of the audio-visual contemporary culture, can shelter perhaps an act of desire of which certain subject demonstrates be responsible. We direct, thus, our interest in the level of statement of the text, a level integrated by figures of subjectivity with places defined by the plot, but a level also that demonstrates the friction of the subject with the Language since his desire must make a path in the code. Nevertheless, it is possible that the above mentioned friction has been evacuated of the text, so that the offer of this text can be
\end{abstract}


limited to a mere putting in scene, by virtue of which the meeting of the subject with the Language is displaced by the meeting of a Figure with his object in the imaginary level.

Keywords: Text, Enunciation, Advertising, Subject of the Unconscius, Desire.

\section{Introducción}

La génesis de este trabajo se ha inspirado en lo que esta revista, Escritura e imagen, ha señalado como su territorio específico: "las relaciones entre la imagen y la escritura desde una perspectiva interdisciplinar". Cuestión que se explicita en nuestro título, La escritura del deseo en la publicidad televisiva, donde nos hemos interrogado sobre las dos cuestiones para nosotros nucleares: imagen y escritura en tanto susceptibles de relacionarse. Del lado de la imagen hemos convocado una manifestación de la publicidad televisiva, el spot, paradigma de la comunicación audiovisual en su actual forma -e incluso, de lo que ha dado en llamarse cultura audiovisual-; y del lado de la escritura hemos situado el deseo, la escritura del deseo, una noción a la que habremos de comenzar dando forma, y que a priori nos emplaza en el ámbito de la subjetividad, pues stricto sensu el acto de desear será atribuible a un sujeto en el seno de un acto enunciativo. Pues bien, nuestro abordaje del territorio común de la escritura y la imagen exige interrogarnos sobre su origen, el relativo al encuentro primero del sujeto, ése capaz de desear, con la imagen, hecho que tendrá lugar, desde nuestra perspectiva, en el seno del proceso ontogenético, durante la ontogénesis del ser.

Esbozados los derroteros teóricos de este trabajo, he aquí que nuestro objetivo analítico será también acometer la escritura del deseo en el texto publicitario, concretamente en el spot de modelo dominante, aquel de corte seductor. Necesitábamos, pues, un texto en particular e hicimos nuestra elección: se trata del spot producido en octubre de 2007, realizado por el estadounidense David Lynch para la marca Gucci, a propósito del perfume Gucci By Gucci, cuyo lanzamiento se llevó a cabo coincidiendo con los 85 años de la marca. He aquí un texto conmemorativo y, en tanto tal, intrínsecamente memorable: Gucci celebra su nacimiento, su irrupción en el mercado con un texto ejemplar, al que interrogaremos sobre las condiciones en que, en su interior, se (Gucci) escribe el deseo.

Estamos reconociendo el texto publicitario como custodio de un trabajo (de escritura) del deseo, a cuyo sujeto apuntaremos necesariamente en nuestra búsqueda. Estamos suponiendo que aquél es depositario de un acto de deseo del cual un sujeto manifiesta implícitamente ser responsable. Situamos, así, nuestro interés en el nivel enunciativo del texto, ése poblado de figuras de subjetividad ocupantes de 
lugares que la trama define, pero ése también donde se acusa el roce del sujeto con el Lenguaje, con el código, con sus estructuras. Ahora bien, es posible que dicho roce haya sido evacuado del texto, de modo que este último se constituya, antes que en depósito de una tarea enunciativa íntegra, en una puesta en escena, y el encuentro del sujeto con el Lenguaje sea desplazado por el encuentro de una figura con su objeto en lo imaginario. A fin de abordar esta posibilidad, trascenderemos las limitaciones que la Teoría de la enunciación nos plantea, convocando necesariamente, en una tentativa interdisciplinaria, los inestimables préstamos del Psicoanálisis.

\section{En el origen, el encuentro con la Imagen}

Comenzaremos apelando al psicoanálisis, a una consideración de Jacques Lacan que, si bien breve e intrincada, no por ello menos fecunda: "La Ley está al servicio del deseo que ella instituye por la prohibición del incesto"1. Lacan habla de una Ley, de rango universal, que prohíbe el incesto y que en el relato que el autor construye para acometer el proceso de generación del ser (humano), su introducción corresponde a la función paterna: el operador sobre el cual recae dicha función es Le-Nom-du-Père, el concepto lacaniano del Nombre del Padre, que Lacan plantea como el Significante que soporta la Ley del Significante: Ley del mandamiento de la palabra, Ley de la estructura, no pues una ley que se concrete en algún enunciado de autoridad; y Significante que transmite su ley al conjunto de los significantes que integran la cadena, un significante en lo real ${ }^{2}$. Le-Nom (Non) -du-Père se plantea en el pensamiento lacaniano como la represión original ${ }^{3}$, significante capaz de nombrar y separar - prohibiendo la unión entre ambos-a Yo (función filial) y a Tú (función materna) como instancias diferenciadas. Tendrá, así, por objeto pautar lo que el psicoanálisis denomina pulsión: la relación pulsional es interior al Estadio del espejo ${ }^{4}$, el cual se habrá instituido desde el origen entre el hijo y su madre, una relación (especular) en la que éste lo demandará todo de ese Todo que es la madre para él. Esa demanda y esa unión entre madre e hijo, en la que a éste le va incluso la supervivencia, implica que para el hijo al menos no habrá diferencia entre Yo-hijo y Tú-madre, sino el espejismo, e incluso el delirio, de una unidad entre ambos: "Yo y Tú, mi Imagen-Figura de plenitud", a la que reconoce como única, una Figura

${ }^{1}$ Lacan, J., Escritos II, México, Siglo XXI, 1991, p. 831.

2 Rabinovich, N., «El Nombre del Padre: Articulación entre la letra y la ley y el goce», Trivium, Edição II, $2^{\circ}$ semestre (2010), pp. 432-443. Último acceso: 16 de mayo de 2013.

http://www.uva.br/trivium/edicao1-dez-2010/artigos-tematicos/5-articulacion-entre-letra-la-ley-y-elgoce.pdf

3 Véase Lacan, J., El Seminario III: Las psicosis, Buenos Aires, Paidós, 1984.

4 Sobre el Estadio del espejo véase Lacan, J., El Seminario I: Los escritos técnicos de Freud, Buenos Aires, Paidós, 1992; o El Seminario IV: La relación de objeto, Barcelona, Paidós, 1994. 
materna más allá de la cual para Yo sólo habrá fondo. Esa Imagen actúa desde el comienzo de los tiempos como reflejo de Yo, como lo único donde Yo se reconoce, una forma armónica que, en tanto tal, alivia a ese ser vivo que de momento es experiencia de fragmentación, pura angustia.

Pero en el proceso ontogenético habrá de operar necesariamente un Significante que nombre, en un acto de enunciación memorable, a Yo como hecho diferenciado y separado de Tú, pues sólo en la medida en que Yo se reconozca separado de Tú podrá desear(lo), podrá enunciar su demanda y habrá deseo. Es así como tendrá lugar la transformación de la relación pulsional, transida por cierta masa energética que empuja desde el interior de $Y o$, en una relación cifrada en el deseo ${ }^{5}$ de eso que no soy $Y o$, luego que no poseo, pero que en esa misma medida ansío: la Imagen deseable de mí que Tú me devuelve. Ese Significante, en un acto de enunciación de la Ley que prohíbe el vínculo primigenio potencialmente incestuoso, posibilita el deseo y funda el sujeto - diferenciado, atravesado por una herida- del deseo.

El deseo más primitivo emergió de un proceso de desgarro propiciado al narcisismo primero - pues el Estadio del espejo es de índole narcisista-; un desgarro dramático para Yo, provocado por un acto enunciativo introductor de lo real. Lo real, por oposición al reconfortante universo narcisista, es: "un territorio totalmente inhóspito, es el desierto" 6 en que habito, aquí se expresa bien la experiencia de soledad a la que lo real, el mundo en tanto azaroso, distinto y ajeno a mi deseo, nos arroja. Pero a la vez dicho acto será capaz de suturar la herida propiciada a Yo, su particular crisis de identidad, permitiendo el sostenimiento, en tanto figura diferenciada, de la Imagen ahora prohibida, en lugar de su destrucción irremisible por la vía del incesto. Tal como lo expresara Freud7 ${ }^{7}$, el paso de la pulsión al deseo se traduce en la transición desde el principio del placer - toda la pulsión presionando sobre la Imagen-Figura materna- hacia el principio de realidad -una articulación posible de lo pulsional procurada por la Ley simbólica.

\footnotetext{
5 El psicoanalista Adolfo Berenstein plantea que el proceso civilizatorio mismo exige acotar la expansión del goce pulsional a favor de la emergencia del deseo, promover la función del discurso por encima del automatismo pulsional, hacer prevalecer el acto de la palabra sobre el pasaje al acto, permitir el dominio del tiempo del deseo sobre la inmediatez de la pulsión. El tempo del deseo constituye una dilación introducida por la dimensión de la palabra -la dimensión simbólica- sobre la fugacidad del goce pulsional. Sin la escritura del deseo, la fuerza de la pulsión se ligará a la muerte. Y la prohibición será - por oposición a la pulsión- el trazo que alimente el deseo, que reconduzca la pulsión. Berenstein, A., Vida sexual y repetición. (=Psicoanálisis. Clínica psicoanalítica), Madrid, Síntesis, 2010, pp. 185186.

6 Martín Arias, L., «Entre la ideología y el conocimiento», en Actes de Congènere: la representación de gènere a la publicitat del segle XXI, Girona, Servei de Publicacions de la Universitat de Girona, 2010. Último acceso: 7 de noviembre de 2011.

http://www3.udg.edu/publicacions/vell/electroniques/congenere/ponencies/04_ideologia_conocimiento.pdf

7 Véase, al respecto, Freud, S., Más allá del principio del placer, Madrid, Biblioteca Nueva, 1981.
} 


\section{A posteriori, el encuentro con el Lenguaje}

En referencia a la antedicha Ley, he aquí que para Lacan "surge con el significante, de forma interna" 8 , y en otro lugar indica que "proporciona al hombre su mundo propio, ese que, con mayor o menor exactitud, llamamos cultural"9. Lacan plantea el carácter fundador de la Ley de lo genuinamente humano, universo que no tiene parangón en lo real, en el espacio referencial. Una Ley estructurante como el Lenguaje que la soporta, si bien, será garantía de toda posibilidad de cultura no sólo porque introduce un ordenamiento humano ex novo allí donde sólo hay azar, sino en tanto introduce el Interdicto allí donde todo es posible, allí donde no hay límites.

Derivado de lo anterior, diremos que el vínculo primitivo entre Yo y la Imagen, en tanto previo al Significante, será en buena lógica acultural. Sólo con la llegada de la Ley y su asunción se producirá un refinamiento de la pulsión operado por el Significante desde el dominio de la Cultura, introduciendo así a esa materia que somos en origen -apenas experiencia de fragmentación adherida al espejo, a la Imagen que la Figura materna proyecta- en el ámbito del deseo (humano) propiamente dicho. Así, el problema humano fundamental será el del acceso a la Ley, el de la posibilidad de acceder y el del éxito del acceso, pues de ello depende que para cada individuo haya una oportunidad, un modelo posible de articulación de su pulsión en deseo. Si el individuo queda sujeto a la Ley, más allá de la Imagen, del Espejismo, que ahora podrá ser trascendido, la Ley será para él lo deseable.

Freud primero, y después Lacan, habrán contribuido a determinar una estructura en origen, soporte idóneo de un interdicto, una trama, soporte idóneo de un conflicto, capaz de operar la transformación de la pulsión en deseo, de un universo pulsional $\left[y o=t u^{\prime}\right]$ en un universo deseable $[y o \neq t u ́]$, luego [yo, tú, él]. Una trama en la que hay prohibición y en esa medida conflicto, una trama que introduce además una dimensión temporal, un antes y un después de la incorporación al dominio de la Ley, y una que instituye un mito, ya que su desarrollo en los orígenes parece ser lo deseado, cierto ideal de perfección. Dicho mito determinará el nacimiento del sujeto en su dimensión individual y en su dimensión social.

Un mito, una trama, digamos un texto portador de una función simbólica. He aquí el momento de formular la cuestión implícita al título de este trabajo: La escritura del deseo en la publicidad televisiva o de cómo (y si) el texto spot publicitario, en su modelo dominante, toma parte en la operación, humanamente -luego culturalmente-indispensable, de contribuir a transformar-siguiendo la lógica de aquel prototexto- la pulsión en deseo, trascendiendo la adhesión a la Imagen, al espejismo, y haciendo deseable la Ley, el deber-ser. Entendemos que si el texto, el relato

\footnotetext{
8 Lacan, J., El Seminario IV: La relación de objeto, Barcelona, Paidós, 1994, pp. 238-239.

${ }_{9}^{9}$ Lacan, J., El Seminario II: El yo en la teoría de Freud y en la técnica psicoanalítica, Buenos Aires, Paidós, 1990, p. 199.
} 
que el psicoanálisis reconstruye -texto que, si estuvo, constituyó para el sujeto su relato originario-, narra el advenimiento del Lenguaje en tanto vía de instalación en la Cultura; portador de una interdicción, ese hecho de enunciación tendrá, en términos subjetivos, un carácter fundador, constitutivo, en el sentido lacaniano ${ }^{10}$. Ahora bien, ese acto de enunciación, en la práctica, habrá estado acompañado de infinidad de singularidades, por lo que sólo se habrá aproximado al paradigma del mito fundador tal como lo expone el psicoanálisis, en consecuencia, el sujeto no dejará de buscarlo y la Cultura no dejará de repetirlo, a la manera en que se repiten los mitos y con la misma finalidad, esto es, se repite, se actualiza el acto fundador a fin de garantizar la supervivencia del sujeto, reproduciendo la cifra de su fundamentación humana: No dos fundidos en uno solo, sino Tres lugares.

Pues bien, ese texto depositario de una protoestructura, en la que al menos se reconocen tres posiciones representadas por la función paterna, la función materna y la función filial, habrá articulado una separación entre los elementos que la integran, prohibiendo explícitamente la fusión de dos de ellos. Luego todo texto -al menos aquéllos fieles al patrón del mito constitutivo del sujeto- será un hecho del Lenguaje, un acto enunciativo, en su encuentro necesario con la Ley fundadora de toda Cultura, el Interdicto, y por ello también será quien de conducir a las figuras de subjetividad que lo habitan a un encuentro con lo real. Lo real, eso otro de lo humano, el azar extremo, lo que acaece más allá de toda lógica, de toda expectativa, que embate desde el exterior, al tiempo que será eso irrefrenable que empuja también desde el interior, la pulsión. Y esto, lo real, será el punto de llegada del deseo genuino del sujeto; por tanto, el deseo de fundirse en lo imaginario con el espejismo, con la Imagen primordial, no será sino una quimera, una ilusión, y en tanto tal, una alucinación, una ofuscación, y así debe nombrarlo el Lenguaje en su función de prohibición, enunciando el deber-ser, otorgando una vía humanizante a la pulsión, una que apunte al territorio de lo real, de ahí que la Ley funde el principio de realidad para el sujeto11. El verdadero deseo (del sujeto) estará no en la

10 "Las palabras fundadoras que envuelven al sujeto son todo aquello que lo ha constituido, sus padres, sus vecinos, toda la estructura de la comunidad, que lo han constituido no sólo como símbolo, sino en su ser". Lacan 1990, op. cit. (nota 9), p. 37.

11 "La pérdida del objeto es ante todo la pérdida de sus propiedades naturales en tanto que objeto de la necesidad biológica y de la satisfacción instintiva, pérdida que es solidaria del apresamiento del ser humano por el lenguaje (...) esta pérdida no puede ser pensada como la pérdida de un objeto que alguna vez estuvo, sino como una pérdida estructural en el ser parlante. Es una pérdida vinculada a la transformación que sufren en el ser humano las necesidades biológicas por el hecho de que habla. La necesidad animal implica un organismo en relación directa con su objeto. En el ser humano esta relación aparece perturbada por el hecho de que la necesidad tiene que pasar por el desfiladero de las palabras. Es decir, el sujeto signado por la necesidad, se verá obligado a pedir, a demandar, se encontrará con el lenguaje (...) La demanda, esto es el lenguaje, el significante, transforma la necesidad, la oblitera, en su naturalidad biológica. El término deseo se puede situar como el resultado de esta sustitución de la 
Imagen (primordial) sino en lo real, en su enfrentamiento gozoso -he aquí el goce de lo real-, para lo cual los textos -al igual que aquel primer texto- podrán ofrecer una vía en los términos del deber-ser. En este sentido, ni la Cultura, ni sus artefactos, verbigracia los textos, dan la espalda al universo referencial, sino que constituyen una manera deseable de acometer nuestro ineludible ser-en-el-mundo, nuestra condición, por ello diremos de esos textos que son radicalmente realistas.

Todavía, el texto del que hablamos, el texto edípico, un texto subjetivo, y aquellos otros que en adelante alberguen, a modo de núcleo, la trama que aquél instauró para cada sujeto en cuestión, se caracterizarán porque trascienden toda relación especular, imaginaria, apuntando a lo real, alrededor del cual realizan todo un trabajo de acotamiento, y ahí habremos de situar el trabajo de escritura del deseo: a partir de significantes que, en tanto portadores de prescripciones y prohibiciones -he aquí la dimensión del deber-ser que hallará soporte en el Lenguaje-, se rozan lo justo con lo real, permitiendo así al sujeto padecerlo, gozarlo y, tras ello, salir fortalecido en virtud de una gesta. De ahí la magnitud (antropológica) de estos textos, pues a través de ellos podemos entrar en contacto con el sujeto que nos habita -constituido necesariamente gracias a una trama de lugares permitidos y prohibidos-, el sujeto del inconsciente, el sujeto del deseo que apunta al goce de lo real; los textos nos proporcionan cierto saber sobre él y sobre ello.

Y bien, derivado del planteamiento anterior, una cuestión sobre el sistema de análisis que proponemos, pues éste se pretende ordenado y ordenador del texto, un acto de inteligibilización, aunque no sólo, también y sobre todo un acto subjetivo, una tentativa de involucrar al sujeto que llevo dentro con la pretensión de ofrecerle un acto experiencial de un hecho textual, capaz de afectarle, de tocarle íntimamente, en la medida en que pueda verse seducido, movilizado su deseo, al tiempo que reconducido a un encuentro con lo real tal que contribuya, en virtud de alguna gesta, al refinamiento cultural del individuo, a asumir la deseabilidad de la Ley (fundadora), del deber, de lo debido. El objetivo de nuestro análisis será, entonces, alcanzar la trama nuclear que habrá de hallarse necesariamente en el plano de la estructura narrativa, allí donde una serie de figuras de subjetividad (enunciadores, enunciatarios, personajes...) ocupan los lugares que la trama define. Y ahí, bajo ese entramado, cierta masa energética o pulsional deviene deseo, deseo que discurre entre signos, desgarrándolos, ese es precisamente el acto de escritura: un acto de enunciación, el tránsito de la estructura de la lengua a la estructura del discurso, tránsito en virtud del cual el deseo habla y su sujeto se manifiesta. El deseo es la experiencia subjetiva, íntima, que busca con determinación -y ahí se localiza cierta angustiaser escrita, ser enunciada. Enunciación, escritura, he aquí el trabajo textual (capaz

necesidad por la demanda. En esta sustitución se genera un resto que queda perdido, inarticulado en la demanda, este resto, que no puede ser articulado en la demanda, se convierte en la causa del deseo." Castrillo, D., «Necesidad, demanda, deseo», en Reyes, R., (dir.), Diccionario crítico de ciencias sociales, Madrid-México, Plaza y Janés, 2009, pp. 1-7. 
de hacer aflorar) del deseo. Un trabajo del cual el deseo es a la vez sujeto y objeto, pues en el texto el autor, el equipo y el lector, o el espectador, trabajan en virtud de su deseo en el ámbito (áspero) de la representación y son allí también trabajados por esa trama, la única capaz de enunciarlo, de escribirlo.

\section{Lo que la Semántica aporta al estudio del texto}

Apelemos, a continuación, a la noción de cultura planteada por Émile Benveniste: "Llamo cultura al medio humano, todo lo que, más allá del cumplimiento de las funciones biológicas, da a la vida y a la actividad humana forma, sentido y contenido"12, adviértase que en los hechos de cultura queda comprometido algo, sea lo que fuere, a lo que se denomina sentido. Y continúa: "consiste en una multitud de nociones y prescripciones, también en prohibiciones específicas; lo que una cultura prohíbe la caracteriza al menos tanto como lo que prescribe. El mundo animal no conoce prohibición alguna"13; lo prescrito y lo prohibido marcan inequívocamente los límites de lo cultural -que son a la vez los límites de lo humano-, la frontera entre lo propio e impropio de una cultura, lo que puede o no considerarse hecho de cultura. Por último, "ahora, este fenómeno humano, la cultura, es un fenómeno enteramente simbólico. La cultura se define como un conjunto muy complejo de representaciones, organizadas por un código de relaciones y valores: tradiciones, religión, leyes, política, ética, artes, todo aquello que, nazca donde nazca, impregnará al hombre en su conciencia más honda, y que dirigirá su comportamiento en todas las formas de su actividad"14; en esta perspectiva, la cultura es un fenómeno inmaterial por oposición a lo material -e incluso, a la matericidad- del universo referencial.

Introduzcamos ahora un argumento de Gianfranco Bettetini, semiólogo integrado a diferencia de Benveniste, que habrá ultrapasado ciertos límites en lo epistemológico. Bettetini plantea lo siguiente a propósito de un antropólogo que ha incorporado la razón semiótica a su abordaje de la cultura:

Las consecuencias del «salto» filosófico de Lévi-Strauss pueden enfocarse desde dos opciones paradigmáticas contrapuestas: o bien la cultura no es sino la estructura de la naturaleza «convertida en objeto por sí misma», o bien la cultura es únicamente discurso, lenguaje que remite continuamente a sí mismo, en una infinita progresión de actos significantes. En el primer caso, en la «naturalización total de la cultura», volvemos a encontrarnos ante un materialismo vulgar ya superado; en el otro caso, se nos propone

\footnotetext{
12 Benveniste, E., Problemas de lingüistica general I, México, Siglo XXI, 1997, pp. 31-32.

13 Ibidem, pp. 31-32.

14 Ibídem, pp. 31-32.
} 
un escepticismo metafísico. Pese a las confesiones de «materialismo» de Lévi-Strauss (véase Le Monde, 14-VII-62) nos sentimos más inclinados a vincularle al punto de vista epistemológico que ofrece el segundo caso de la contraposición. Y ello porque en sus escritos se manifiesta una idea fundamental: el lenguaje es el modelo que permite el estudio de todos los fenómenos humanos y que llega a ser, por consiguiente, el polo de referencia de todas las ciencias humanas. ${ }^{15}$

He aquí la propuesta: todo es lenguaje, y todo en la cultura, en el medio humano, todo lo genuinamente humano responde al modelo del lenguaje, luego todo lo que afecta al hombre se agota en el lenguaje.

También para Benveniste todo parece responder al patrón de la lengua, desde luego la cultura en tanto enteramente simbólica, e igualmente el pensamiento que respondería a los límites impuestos por la lengua, no pudiendo ser captado más que formado y actualizado en aquélla. La lengua organizaría lo que se puede pensar y delimitaría lo que puede ser dicho, como sucediera con las prescripciones y prohibiciones de la cultura. Sin embargo, matizando esta consideración, en contra de la ortodoxia semiótica, inopinadamente, Benveniste introduce la noción de $\operatorname{ser}^{16}$, del cual se dice que lo envuelve todo y que, sin tratarse de un predicado, es la condición de todos los predicados. Introduce así al sujeto, condición (primera) de todo predicado, de todo aquello que pueda ser dicho en cualquier proposición. Benveniste sitúa la relación entre la lengua, condición en su sistematicidad del pensamiento, de la cultura, y el ser, condición a su vez de todo predicado, esto es, de todo discurso; he aquí la cuestión de(1) ser-en-el-lenguaje, que es la cuestión de la enunciación y la escritura ${ }^{17}$.

Y bien, la lengua sería el sistema común a todos los individuos, sistema de referencia, mientras que la palabra, el discurso, resultaría de someter a intereses individuales e intersubjetivos dicho sistema: las conformaciones de la palabra serán únicas cada vez, a pesar de realizarse en el interior y por mediación del lenguaje ${ }^{18}$. Luego la relación del sujeto con el lenguaje se manifiesta como una relación conflictiva; la relación con el sistema, el código, se salda con el surgimiento de la palabra en el marco de la generación del discurso, producto del trabajo subjetivo, de la fricción de la escritura, de la necesidad particular, singular, de expresión del sujeto, y en tanto tal, en parte intransferible, en los márgenes de lo transmisible. Precisamente, para explicitar la relación del sujeto con la lengua, lo conflictivo de

15 Bettetini, G., Producción significante y puesta en escena, Barcelona, Gustavo Gili, 1977, p. 39. 16 Ibidem, p. 39.

17 Desde los años 80, el profesor Jesús González Requena ha venido situando la cuestión de la enunciación como el modo que ha tenido la semiótica de abordar la subjetividad, incorporándola a su teorización del texto, ese particular cruce entre la semiótica y el psicoanálisis en cuya senda se sitúa este artículo.

18 Benveniste 1997, op. cit. (nota 6), pp. 77-78. 
la misma, Benveniste hará referencia a la experiencia psicoanalítica, donde el analista habrá de atender, más que al contenido del discurso, a sus desgarros ${ }^{19}$. Benveniste señala la presencia de agresiones hechas al discurso, fisuras resultado de la apropiación del código por parte del sujeto, fruto del trabajo enunciativo. Desgarros, incisiones que conducen a otra dimensión más allá del código, la del ser, la correspondiente al núcleo del deseo (inconsciente), desde donde el sujeto realiza un particular trabajo enunciativo, uno que se abre camino adoptando y rasgando el código, uno que hace discurso, si bien uno absolutamente particularizado.

Desgarros del discurso, desfallecimientos de la actividad verbal, libre divagación del sujeto cuando queda suspendido el poder de censura, todo ello sería la manifestación de cierta fuerza anárquica que refrena o sublima el lenguaje normalizado, aunque con limitaciones, y cuyo origen es el inconsciente 20 . He aquí al inconsciente -al sujeto (del inconsciente)-, fuerza anárquica (pulsional) en litigio con un lenguaje que le refrena, reprime, mitiga, o que le sublima. Se nos plantea, así, la cuestión enunciativa, el trabajo de la escritura (del deseo), en los términos de un choque, un roce de esa fuerza pulsional que nos habita contra la norma, contra el código que la constriñe. Algo procedente del inconsciente, la pulsión en suma, presiona para desencadenar, en su fricción con el código, un acto de enunciación particularizada, subjetivizada, en virtud del cual el deseo (reprimido) pueda ser formulado.

De la cuestión del conflicto entre el sujeto del inconsciente y el código, la argumentación de Benveniste se traslada necesariamente hacia el sentido: “¿Qué no se habrá intentado para evitar, desconocer o expulsar el sentido? Por mucho que se haga, esta cabeza de Medusa sigue siempre enfrente, en el centro de la lengua, fascinando a quienes la contemplan" 21 . Y más adelante, "cuando se dice que tal o cual elemento de la lengua, corto o dilatado, tiene un sentido, se entiende por ello una propiedad que este elemento posee en tanto que significante, de constituir una unidad distinta, opositiva, delimitada por otras unidades, e identificable para los locutores nativos, de quienes esta lengua es la lengua. Este "sentido" es implícito, inherente al sistema lingüístico y a sus partes" 22 . El sentido podría plantearse como una desviación con respecto al código, pues implica que ciertas unidades procedentes de éste son apropiables e identificables como particulares por los interlocutores que manejan una determinada lengua. Diremos, entonces, que el sentido es el producto de una relación particularizada entre el sujeto y el lenguaje en un singular acto de habla.

Benveniste da entrada, así, a cuestiones a las que la semiótica saussuriana había dado la espalda: el sujeto, el sentido, la enunciación, el discurso. Él mismo afirma

\footnotetext{
19 Ibidem, pp. 77-78.

20 Ibidem, pp. 77-78.

21 Ibídem, pp. 124-125.

22 Ibidem, p. 126.
} 
el carácter cerrado del mundo del signo, de manera que entre éste y la frase no habría transición posible, ambas esferas estarían separadas por un hiato. Sin embargo, al reconocer en la lengua dos dominios distintos, puede proponer sendos aparatos conceptuales: uno semiótico, para el que la teoría saussuriana del signo lingüístico habría servido de base, y uno semántico, a cuyo aparato conceptual Benveniste hará aportaciones, contribuyendo a una semiología de segunda generación, que más allá de la noción saussuriana del signo, de la cual dependerían la estructura y el funcionamiento de la lengua, apuntará al discurso, depósito de una nueva dimensión de significancia. He aquí una propuesta de caminos diferenciados para la semiótica y para la semántica, siendo desde el ámbito de la semántica, el de la enunciación, que se abrirá una puerta al reconocimiento del texto como susceptible de estudio en tanto resultado de un acto enunciativo.

\section{Enunciación, comunicación, experiencia}

Abordaremos, a continuación, la cuestión relativa al repertorio de figuras de subjetividad que podemos hallar en todo marco discursivo, sobre quienes recae en primera instancia el acto enunciativo. Tal como lo plantea Benveniste, en un hecho de discurso Yo y Tú "son inversibles: aquel que «yo» define como «tú» se piensa y puede invertirse a «yo», y «yo» se vuelve un «tú»" 23 , sin embargo, ninguna relación parecida es posible entre alguna de estas dos personas y Él. Así, Yo siempre presupone desde el discurso un Tú, luego la relación que se instaura entre ambos es de reversibilidad, una relación dual, y en tanto tal, una relación exclusoria, de manera que el tercero, la tercera persona quedará erradicada. Pues bien, en otro lugar el autor señala:

El lenguaje es pues la posibilidad de la subjetividad, por contener siempre las formas lingüísticas apropiadas a su expresión, y el discurso provoca la emergencia de la subjetividad, en virtud de que consiste en instancias discretas. El lenguaje propone en cierto modo formas «vacías» que cada locutor en ejercicio de discurso se apropia, y que refiere a su «persona», definiendo al mismo tiempo él mismo como yo y una pareja como tú. La instancia de discurso es así constitutiva de todas las coordenadas que definen el sujeto, y de las que apenas hemos designado sumariamente las más aparentes. ${ }^{24}$

Convendremos con Benveniste en que el discurso define una serie de formas de subjetividad útiles, necesarias, en un acto de habla, ahora bien, primeramente debe objetarse que el autor define la subjetividad -y sus formas- en el marco exclusivo

\footnotetext{
23 Ibidem, p. 166.

24 Ibidem, p. 184.
} 
de su proyección comunicativa, y en segundo lugar, debe añadirse que es en el texto donde el sujeto verdaderamente se manifiesta, pues atendiendo a la noción de texto que manejamos, al ser ésta más amplia que la de discurso, englobará los intersticios, los desgarros de los que otrora hablara el autor, a través de los cuales emerge el sujeto del inconsciente a costa de su pugna con el código. He aquí que el núcleo de la subjetividad, en su particular acto enunciativo, ultrapasa necesariamente los límites del lenguaje, sus formas, sus figuras. Por ello, el sujeto de la enunciación no coincide con el sujeto empírico que toma la palabra, o irrumpe en la imagen, esto es, la fuente de la enunciación; ni coincide con el sujeto del enunciado, ése que resulta nombrado en el proceso discursivo; como tampoco coincidirá con el sujeto enunciador-modelo, el ideado por el lector o el espectador empírico en su acceso al discurso 25 .

En todo caso, Benveniste plantea la enunciación de modo que antes de ésta la lengua no es más que posibilidad, y sólo tras el acto enunciativo ésta se materializará en una instancia de discurso procedente de un locutor, que aguarda un auditor y que desencadena otra enunciación a cambio 26 . El acto enunciativo será, en esta lógica, acto de intercambio, uno que se quiere reversible, acto de comunicación que como tal prevé un cuadro figurativo integrado por dos figuras necesarias: una fuente, la otra término, de la enunciación, y ambas ocupando la posición de interlocutores que protagonizan alternativamente el acto enunciativo 27 . Ahora bien, proponemos que la enunciación no se agota en esto, que tal concepción debe ser trascendida, pues más allá del discurso, el texto que lo contiene es producto de un acto íntimo en el que $m i$ sujeto manifiesta, a costa de una particularizada pugna con el código, una experiencia a priori intransferible, por absolutamente singular, por haber sido padecida en soledad, la de su constitución en tanto fue, por definición, dramática.

Atendamos todavía a otra consideración de Benveniste:

Hay que introducir aquí un término que el análisis semiótico no requería: el de «referente», independiente del sentido, y que es el objeto particular al que la palabra corresponde en lo concreto de la circunstancia o del uso (...) Si el «sentido» de la frase es la idea que expresa, la «referencia» de la frase es el estado de cosas que la provoca, la situación de discurso o de hecho a la que se refiere y que jamás podemos ni prever ni adivinar. En la mayoría de los casos, la situación es una condición única, cuyo conocimiento no puede ser suplido por nada. De suerte que la frase es cada vez un acontecimiento diferente; no existe más que el instante en que se la profiere, y se borra en el acto; es un acontecimiento evanescente. 28

\footnotetext{
25 Véanse las consideraciones de González Requena en el prólogo del texto de Bettetini, G., La conversación audiovisual. Problemas de la enunciación fílmica y televisiva, Madrid, Cátedra, 1986, p. 10. 26 Benveniste, E., Problemas de lingüística general II, México, Siglo XXI, 1997, p. 84.

27 Benveniste 1997, op. cit. (nota 19), p. 88.

28 Ibidem, p. 229.
} 
He aquí la extrema singularidad y, en tanto tal, lo irrepetible de aquello (lo referencial) - exterior a mí- que desencadena el acto de habla, el acto de enunciación. Sólo el sujeto que me habita puede acusar y hacerse cargo de lo referencial, lo irrepetible, esas condiciones - experimentadas como- contingentes que, desde el exterior, contribuyen a propiciar el texto. En suma, algo empuja desde el interior del sujeto, una experiencia que precisa ser escrita, y algo incide desde el exterior del sujeto marcando, poblando de huellas, ese hecho textual que, en ambos sentidos, se hace necesario.

\section{El sujeto de la enunciación en estado crítico}

Atendiendo de nuevo a Bettetini, éste plantea lo que sigue:

No se sabe ya quién habla a través de la pantalla, dentro de la pantalla; o mejor, ya no interesa esta información, no se quiere saber con quién se comunica. La llegada de las nuevas tecnologías electrónicas, el crecimiento hiperbólico del número de los canales de emisión, el enlace en redes de los mismos canales, a menudo materialmente deshomogéneos (aire, cable, satélite), han hecho que se precipite rápidamente la noción del «sujeto enunciador» audiovisual desde la esfera de los tratados y de las disquisiciones científicas, a la concreción de uno de los problemas más agobiantes de la vida común del contexto social contemporáneo. ${ }^{29}$

Luego la proliferación y diversificación de las fuentes de emisión de discursos habrá acarreado un desconocimiento, a la vez que un desinterés, por saber quién se hace cargo de la palabra o la imagen. En el actual marco de la comunicación mediática, la cuestión de la enunciación no parece ser relevante.

El autor expone, no obstante, la diferencia entre dos figuras discursivas: el sujeto de la enunciación -objeto de la semiótica- y el sujeto empírico -trasladado a otros marcos disciplinares-: "El sujeto de la enunciación que preocupa a la investigación lingüística es sólo el producto cultural de una instancia de ordenamiento y jerarquización, por lo que es verdaderamente subyacente a una trama de prácticas significantes y de proyectos comunicativos" 30 . Ese sujeto al que Bettetini se refiere sería un efecto del discurso, uno más de sus operadores, si bien éste al servicio de su óptima estructuración, de su buen funcionamiento comunicativo. En cuanto a la segunda figura, se correspondería con: "el sujeto que enuncia concretamente, con su cuerpo, y que produce la situación empírica del intercambio comunicativo (...) este sujeto empírico, a diferencia del que se refiere a la enunciación, es concreta-

\footnotetext{
29 Bettetini 1986, op. cit. (nota 18), p. 14.

30 Ibidem, p. 28.
} 
mente un origen, un principio activo: su subyacencia tiene un carácter secundario respecto a su presencia y al papel que desarrolla enunciando"31.

Para el autor, para la disciplina a la que representa, el discurso produce la instancia de su sujeto, al tiempo que el destinatario produce también su simulacro de autor modelo o autor implícito, instancia que puede o no coincidir con aquella otra que el texto emplaza como sujeto de la enunciación. De todo ello interesa destacar que este sujeto de la enunciación no realizará trabajo alguno de escritura -tal y como nosotros lo hemos planteado-, no posee esa atribución, siendo apenas un freno a la caotización del discurso, o lo que es lo mismo, en tanto instancia estructurante del discurso será garantía de sus condiciones de inteligibilidad, de legibilidad. Y así, para la semiótica, puesto que el sujeto de la enunciación no es sino una instancia comunicativa, no habrá noción posible de texto al margen de la noción de discurso: "Un texto puede ser, además, definido como una máquina semiótica que transfiere el saber organizado por el sujeto de la enunciación (el cual, no nos cansaremos de repetirlo, es al mismo tiempo productor y producto del texto) a un sujeto enunciatario: es la manifestación contingente de aquel saber en una práctica discursiva encaminada a su traspaso"32. El texto se define en términos de transitividad, pues su función será hacer llegar cierta información a un receptor, y en esa medida no se plantea como un espacio resistente, poblado de escollos, fisuras y opacidades. En estas condiciones puede sostenerse la existencia -e incluso, la deseabilidad- de una conversación protagonizada por los dos simulacros interiores al texto, el sujeto enunciador y el sujeto enunciatario: "que miran respectivamente a la organización de la producción de sentido del texto y a la dirección de la correspondiente relación de recepciones (sujeto enunciador); a las modalidades de la misma recepción y a la definición de los correspondientes recorridos de sentido (sujeto enunciatario)"33. Hay, en esta perspectiva, una relación comunicativa inherente al texto en la que todo se agota, que exige la presencia de una instancia organizadora que señale los posibles recorridos del sentido que allí se albergan, lo que habrá de permitir a su enunciatario una óptima decodificación.

Sin embargo, en el actual panorama de proliferación de fuentes de emisión, he aquí que el autor reconoce la escasa operatividad de la función comunicativa del texto, esto es, del discurso, luego podría reconocerse la inoperancia de una aproximación afanada en reconstruir las condiciones de una conversación que, en la práctica, difícilmente tendrá lugar:

Con un texto se puede dialogar y conversar; con un flujo indiferenciado de datos y de noticias se juega o se limita a actos descoordinados de consumo; con la performance

31 Ibídem, p. 28.

32 Ibidem, pp. 80-81.

33 Ibidem, p. 110. 
que multiplica los sujetos empíricos y simbólicos de sus enunciaciones es imposible establecer interacciones comunicativas y se termina por desplazar el intercambio a un nivel de estimulación y de respuesta comportamental. La espectacularidad global de lo cotidiano es muda. ${ }^{34}$

Diremos, pues, que sólo en la medida en que la noción de discurso pueda ser trascendida y resituada en el marco textual, podremos dar cuenta del tránsito de la relación comunicativa a una relación de consumo, así como de la consiguiente crisis de las instancias subjetivas del discurso, enunciador y enunciatario, en tanto instancias comunicativas, a causa de las características del consumo mediático 35 . Pero habremos de dar cuenta, igualmente, del grado de afectación de esta crisis al texto como forma organizada y coherente de saber; saber cuya instancia generadora será el sujeto, acaso afectado, en su manifestación textual, por dicha crisis.

\section{El texto, vía de conocimiento}

Retomemos la consideración hecha del texto como ámbito organizado de saber, pues en términos semióticos dicho saber suscitará múltiples interpretaciones, y así, como en su día lo planteara Eco, una obra será: "Un objeto dotado de propiedades estructurales definidas que permitan, pero coordinen, la alternativa de las interpretaciones, el desplazamiento de las perspectivas"36. Lo propio de una obra será la apertura, la posibilidad de que sean muchos sus abordajes: "La apertura es, por consiguiente, bajo este aspecto, la condición de todo goce estético, y toda forma susceptible de goce, en cuanto dotada de valor estético, es «abierta». Lo es, como se ha visto, aun cuando el artista tienda a una comunicación unívoca y no ambigua"37. Se relacionan, aquí, función comunicativa, apertura y goce estético, de lo cual para nosotros será relevante el hecho de que en la obra (de arte), y en nuestra perspectiva en el texto, puede quedar comprometido el goce.

En otro lugar, y en relación a Opera Aperta, el texto de Eco que venimos de citar, Jorge Lozano señala: "Hay que recordar también que este libro presemiótico se escribe en la lengua franca del informacionalismo, de la Teoría de la Información. Si la información era analizada por Shanon -Teoría matemática de la comunicación (1949)- de modo análogo a como Boltzmann analizaba la entropía, Eco en esa estela relacionaba el arte con el desorden y, por tanto, con la entropía y

\footnotetext{
34 Ibidem, p. 144.

35 Bettetini, G., Fumagalli, A., Lo que queda de los medios. Ideas para una ética de la comunicación, Ansoáin, Ediciones Universidad de Navarra, 2001, pp. 113-114.

36 Eco, U., Obra abierta, Barcelona, Ariel, 1979, p. 34.

37 Ibidem, p. 126.
} 
con la información"38. Pues bien, ambas citas nos permiten preguntarnos por la relación entre el goce estético, del que hablara Eco, y la entropía, apuntada por Lozano, entendiendo que el texto (artístico) está relacionado con el desorden, con la introducción de cierto grado de entropía, y ello pudiera ser la vía de acceso al goce.

Pero volvamos a la apertura, pues a través de ella podremos recuperar a su vez la cuestión del sentido, de la mano de un eficaz lector de Eco como es Jorge Lozano: "Eco recuerda que para «sentido» Hjemslev utilizaba la palabra danesa mening, pero no tanto en el sentido de «significado» como en el de «dirección», al modo en que en una ciudad existen sentidos permitidos y sentidos prohibidos. Y drástico, afirma, «hay cosas que no se pueden decir»" 39 . El sentido se asimila a la direccionalidad, de modo que la citada apertura permitiría múltiples sentidos, pero no todos. Ahora bien, ¿y si en esa multiplicidad de sentidos pudiese establecerse una jerarquía?, ¿y si el texto orientase al sujeto sobre todo en la dirección, en el sentido del goce?, una dirección necesariamente entrópica, no comunicativa, entendiendo por entropía eso que con anterioridad hemos reconocido como los desgarros del código.

De nuevo en la perspectiva semiótica, diríase que el acceso al texto requiere del destinatario cierta competencia para extraer de aquél lo que no dice explícitamente, sino que presupone, promete, implica. De este modo contribuye a rellenar espacios vacíos, a conectar lo que el texto contiene con el amplio tejido de intertextualidad del cual procede 40 y al cual apunta necesariamente, luego: «Un texto (además de un instrumento para inventar o recordar) es un instrumento para olvidar, o al menos para hacer que algo se vuelva latente.» 41 Para intentar avanzar en esa línea acudiremos a otro autor, Luis Martín Arias, allí donde, al margen ya del discurso semiótico, señala: "el sentido de la vida sólo puede ser conquistado a través del método gnoseológico-poético, cuya máxima, según Sócrates, es «conócete a ti mismo». Ya no se trata sólo de tantear, mediante los hechos empíricos, lo real exterior, sino de explorar lo más complicado y problemático: lo real interior que nos constituye y habita" 42 . Sólo así será posible, al tiempo que deseable, el establecimiento de verdades subjetivas, sólo en la medida en que el texto no se agote en su estructura lógico-formal, sino que algo en él pueda latir o presionar para manifestarse, en tanto ámbito de la metáfora, de la representación. El texto puede llegar a constituirse en espacio/tiempo experiencial para un sujeto dado, permitiendo su actualización abordar cierta verdad subjetiva ${ }^{43}$. La suya será una vía subjetiva hacia el conocimiento

\footnotetext{
38 Lozano, J., «Listas, enciclopedias, laberintos: semiótica de la cultura en Umberto Eco», en Eco, U., Cultura y semiótica, Madrid, Ediciones Pensamiento, 2009, pp. 15-16.

39 Ibídem, p. 18.

40 Ibidem, p. 19.

${ }^{41}$ Eco 2009, op. cit. (nota 31), p. 46.

42 Martín Arias 2010, op. cit. (nota 2), p. 2.

43 Martín Arias, L., «El falo y la $\sqrt{ }-1 »$, en El relato. VI Congreso internacional de análisis textual,
} 
-no hacia el olvido, como Eco pretendiera-, a la manera del mandato socrático, conocernos a nosotros mismos en tanto que -y aquí introducimos un planteamiento freudiano- sujetos pulsionales, habitados por la pulsión de muerte "y el deseo de asesinato del otro como desvarío para eludir la propia muerte (Elias Canetti)" 44 .

Desde nuestra perspectiva, lo que late en el texto es una presencia, la correspondiente al sujeto de la enunciación, ése al que hemos hecho referencia desde el comienzo, y que ahora retomamos, en la línea lacaniana, a través de Jacques-Alain Miller: "la condición, entonces, para distinguir al sujeto de la enunciación, es que pueda tomar distancia respecto a lo que él mismo enuncia. Es el sujeto que puede percatarse de que ha dicho algo pero no sabe por qué, o que no cree en lo que ha dicho, o sabe que es una broma, o piensa lo contrario de lo que dice. Es el sujeto capaz de juzgar lo que dice y lo que hace" 45 . Además de añadir que ese sujeto también puede creer en lo que dice o hace, resulta relevante el estatuto que aquí se le concede, siendo aquél que no domina todos los resortes del (de su) enunciado, luego puede objetarse a la semiótica que no todo en el texto responde a una estrategia (controlada). Miller lo plantea de modo explícito:

En el hombre sin embargo, en la humanidad, no es mental todo lo que no es físico. Hay algo que no es mental, aunque pueda parecerlo. Es el pensamiento que Freud llamó inconsciente (...) Lo que impide la mens sana y el cuerpo sano es la existencia disarmónica de un pensamiento. ¿Cuál es la definición más clásica de la salud? La salud se define por el silencio de los órganos. Pero está el inconsciente que no se calla nunca, de manera que no ayuda a la armonía. 46

El psicoanálisis incorpora a lo mental y a lo físico el pensamiento inconsciente, que no es mental ni físico, y que opera sobre ambos desordenándolos. El pensamiento inconsciente será lo que late introduciendo desorden, acaso entropía, atentando contra la buena salud, esto es, contra la armonía del discurso. Consideramos, entonces, que el texto es, en efecto, el ámbito de cierta latencia, el lugar donde late una respuesta, donde el sujeto dice ser responsable de algo:

Y ése es el fundamento del lazo social y lo que Freud descubrió, el punto de vista psicoanalítico sobre la sociedad. Freud no definió la sociedad por la salud mental, sino a partir de un mito, y no cualquiera: el de un crimen primordial en el origen de la Ley. Es el mito que dice: Todos culpables. Es la respuesta mítica al «yo me siento responsable de no sé qué», la respuesta de la muerte del padre. 47

Universidad de Vallladolid, 2010. Último acceso: 7 de noviembre de 2011.

http:/www.tramayfondo.com/actividades/congreso-VI/actas/luismartinarias.html

44 Ibidem.

45 Miller, J.-A., Salud mental y orden público, Granada, Editorial Universidad de Granada, 2010, p. 28.

46 Ibidem, pp. 43-44.

47 Ibídem, p. 29. 
Y añade Miller que, de este modo, puede comprenderse por qué Lacan aconseja que se rechace de la experiencia analítica a los canallas, pues el sujeto canalla sería aquél que siempre encuentra disculpas para todo 48 , aquél cuyo discurso es exculpatorio, por tanto, aquél que erradica al sujeto de la enunciación, del inconsciente, de la culpa. Trasladados ahora al texto publicitario cabría preguntarse: ¿y si éste, al menos en su modelo dominante, se situase en esta vertiente, a saber, en la exculpación, luego en la neutralización del sujeto de la enunciación y, en consecuencia, apuntase como efecto al encanallamiento (social)?

\section{Texto publicitario, texto televisivo}

En nuestro abordaje del spot de modelo dominante, comenzaremos con una reflexión de Sánchez-Biosca, la cual nos permite sortear la sima que pudiera advertirse, a priori, entre las cuestiones de carácter más teórico que hemos abordado hasta el momento y el análisis que nos disponemos a realizar de un spot concreto, apenas una pieza publicitaria emitida entre una maraña de manifestaciones similares:

Realizamos deliberadamente un salto enorme entre, por una parte, el corpus concreto de manifestaciones audiovisuales (caracterizado por su aparente marginalidad y dudoso gusto) y, por otra, los problemas teóricos de indudable alcance estético, filosófico y sociológico (la muerte, la legitimidad de la palabra o los ceremoniales y rituales de nuestra sociedad). Esta fractura puede sorprender, pero estamos convencidos de que nada como la moderna cultura de masas (y, en particular, la audiovisual) para expresar un imaginario propio de nuestra época que no podría encontrarse, al menos con tanto dramatismo y elocuencia, en la literatura o el arte cultos. ${ }^{49}$

La representatividad de la imagen (audiovisual), su carácter paradigmático desde el punto de vista cultural, la hace merecedora, entonces, de un abordaje teórico (y analítico) en toda su densidad. Ahora bien, allí donde el autor habla de la imagen como ámbito de expresión de cierto imaginario, dado que esta consideración nos resulta ambigua, habremos de reformularla a través de Georges DidiHuberman, quien define nuestra contemporaneidad en los términos de un "mundo ahíto, casi ahogado, de mercancía imaginaria" 50 . Y así, hablaremos de la representatividad sociocultural de esos textos audiovisuales que son los publicitarios, en tanto han sido sometidos a un proceso, a una lógica, en definitiva a una estrategia de imaginarización plena.

48 Ibídem, pp. 29-30.

49 Sánchez-Biosca, V., Una cultura de la fragmentación. Pastiche, relato y cuerpo en el cine y la televisión, Valencia, Filmoteca de la Generalitat Valenciana, 1995, p. 12.

50 Didi-Huberman, G., Imágenes pese a todo. Memoria visual del Holocausto, Barcelona, Paidós, 2004, p. 109. 
Pero vayamos por partes, e intentemos definir el estatuto del spot en el marco televisivo. Para la semiótica, la relación del espectador con el discurso mediático, sea cual fuere el medio de comunicación social de procedencia, se abordará en los términos de un proceso comunicativo. Dicha relación se acomete, entonces, a partir de categorías y estructuras propias del modelo comunicativo, donde una instancia emisora, la cadena televisiva en este caso, emite mensajes destinados a un colectivo de receptores, los telespectadores, quienes los decodifican. No obstante, cabría objetar que, más allá del despliegue puntual del paradigma comunicativo, son criterios de carácter empresarial los que gobiernan las instituciones televisivas en primera instancia: "obtener la mayor cantidad de espectadores la mayor cantidad de tiempo posible" 51 . Luego lo relevante para estas empresas será asegurarse el contacto, exigencia que se traslada a todos sus discursos y que se incrementa en lo tocante a la publicidad. Cada segmento de emisión tendrá un valor económico preciso en dependencia directa de su audiencia, de la cantidad y del tipo de espectadores que, en dicho segmento, se encuentren conectados a la cadena, pues se les considera compradores potenciales de los productos publicitados.

Los estudios de audiencias no miden la eficacia comunicativa del proceso que acometen, esto es, la eficaz o ineficaz decodificación de los discursos televisivos, sino el número de espectadores conectados en un momento dado a un determinado canal. El tiempo de contacto, la permanencia de la mirada, serán vendidos por las empresas televisivas a los anunciantes. La paradoja reside en que la televisión, probablemente el medio de difusión de información más influyente en las sociedades contemporáneas, se halla dominada por una lógica no estrictamente comunicativa sino escópica, luego espectacular: "lo que constituye a los individuos en telespectadores, es decir, en sujetos de miradas rentables desde el punto de vista de estas empresas, es su deseo de mirar, de establecer y mantener un contacto visual. Nos encontramos, por tanto, ante un dispositivo destinado a atrapar, a seducir la mirada del espectador"52. Así, la programación se despliega para atrapar el deseo del espectador de cara a venderlo a las empresas publicitarias, de este modo se participa, al menos en parte, del proceso económico, pagando lo que vemos con la mirada. Los spots publicitarios son buen ejemplo de esta lógica (económica y escópica), ya que, al menos en su modelo dominante, el seductor, están al margen de contenidos informativos, el objeto publicitado no se identificará tanto por sus características, sus usos o sus funciones objetivas, como por ser el Objeto del deseo, Imagen fascinante destinada a cautivar la mirada del espectador: "el spot publicitario propone un consumo imaginario, específicamente visual, escópico, del objeto, de su imagen de

51 González Requena, J., Martín Arias, L., «El texto televisivo», Signos. Teoría y práctica de la educación, 12 (1994), p.4.

52 Ibidem, p. 5. 
marca, de su «look»"53. El del spot seductor será un contrato espec(tac)ular donde se minimice la exigencia de decodificación, promoviéndose otra relativa a su consumo visual.

En tales circunstancias, el texto publicitario, y en gran medida el televisivo, aun cuando desplegarán marcas en su enunciación destinadas a procurar el correcto descifrado del texto, del mensaje o mensajes que contengan, por encima de ello, harán un trabajo de despliegue profuso de aquéllas de las que se obtenga una rentabilidad de índole imaginaria, de orden espectacular. Tal será la función expresiva del lenguaje, movilizada para construir la imagen de la fuente del discurso -la imagen de la marca, la imagen de la cadena-; la función conativa, consistente en una interpelación constante al deseo visual del espectador, para el que todo se ofrece, construyéndose así la figura del espectador modelo, del enunciatario, sobre el totalitarismo de su deseo en lo imaginario; y por último, derivado de la omnipresencia de las funciones expresiva y conativa, se habrá de propagar la función fática, la puesta en escena de la relación enunciador/enunciatario, Yo y Tú, en los términos de un contacto intenso, permanente, especular ${ }^{54}$. En suma, ya que todo o casi todo se ofrece a la mirada del espectador, el sujeto enunciador no comparece como un sujeto comunicativo que toma la palabra o la imagen en tanto tiene algo que decir, sino como figura especular plegada al deseo del espectador, mero reflejo de lo que éste pueda desear. En cuanto al enunciatario, será uno enfrentado con el espejo de su deseo una y otra vez hasta el hastío. De modo que, la publicidad de corte seductor, como en general la programación televisiva, se sitúan en lo esencial al margen del lenguaje, al menos en tanto portador de límites, instaurador de prohibiciones, luego el sujeto de la enunciación que aquí late estará condenado a la deriva, en ausencia de todo anclaje, de toda sujeción, impuesta por las pasiones (pulsionales) de la mirada. He aquí un sujeto abandonado en textos a la deriva cuya única salida será la autoaniquilación, pues el texto publicitario constituye el ofrecimiento y la solución mediática, y en cierto modo sociocultural, a su evacuación, su expulsión, su pérdida, su desaparición.

\section{El universo Gucci}

Tal como se ha mencionado con anterioridad, tomaremos como objeto de análisis el spot del perfume Gucci by Gucci realizado por David Lynch para la marca Gucci. He aquí a un experimentado y reputado director de cine que, al menos desde los años 90, ha acometido numerosos spots publicitarios de este tipo: Opium de Yves Saint Laurent, Trésor de Lancôme, Gió de Giorgio Armani, o más reciente-

53 Ibidem, p. 6.

54 Ibídem, p. 8. 
mente Lady Blue Shanghai de Dior. En el caso que nos ocupa, en la línea de los spots anteriores y posteriores, Lynch emplaza al objeto como una suerte de opiáceo que proporciona un estado de éxtasis. Ha contado para ello con la participación de tres modelos, Raquel Zimmerman, Natasha Poly y Freja Beha Erichsen, quienes tendrán tres experiencias idénticas, bailando en trance al ritmo de "Heart of Glass", del grupo Blondie, y aspirando la fragancia que emana del frasco de perfume. El spot fue rodado en París, en el Musée National des Arts D'Afrique et D'Océanie, lo que confiere a los espacios ocupados por las modelos un aspecto exótico, al tiempo que situará bien cierto refinamiento -en tanto el arte queda convocado- que habrá de asociarse al objeto.

El spot comienza con un plano general $(\mathrm{P} 1)^{55}$, una vista aérea panorámica de un paisaje urbano nocturno, tal vez París. La cámara realiza un movimiento de avance sobre dicho paisaje, atravesado por una arteria concurrida, atestada de luces, la imagen parece elaborada según la técnica de la action-painting o dripping, tal como la desarrollara Jackson Pollock, uno de los pintores de referencia de Lynch. Cabe detenerse un instante en esta cuestión, pues Pollock se inscribe en el ámbito del expresionismo abstracto, una corriente en la que se distorsiona, se deforma la realidad por efecto de las emociones, esto es, debido a que algo se trastoca en el plano emocional; pues bien, el modo en que se acomete, formalmente, este plano inaugural constituye el preludio del prolongado delirio que afectará al texto, al universo Gucci, uno de cuyos síntomas recurrentes será la distorsión visual.

Desde el punto de vista cromático, los tonos dorados en contraste con el negro de la noche dominan el plano, por otra parte, una característica cromática del propio frasco de perfume. En cuanto al plano sonoro, desde el comienzo y hasta el final del spot escucharemos "Heart of Glass" del grupo Blondie, Corazón de Vidrio, tema musical que habla del enamoramiento, la apariencia, el espejismo y el desencanto, del amor que parecía verdadero y que, finalmente, sólo era un engaño; de nuevo, ahora desde el plano sonoro, se apela a la difusa frontera entre el ser y el parecer, luego a la experiencia de irrealidad, a lo pseudo.

A continuación, se produce un fundido en virtud del cual se yuxtaponen el anterior plano y el siguiente, el cual nos sitúa en el interior de una estancia, dominada de nuevo por tonos dorados que destacan en la penumbra. Los destellos de luz, la presencia de la luz eléctrica procedente de múltiples fuentes y un movimiento interno de carácter giratorio al tiempo que ondulante, protagonizan el plano. Al fondo de la estancia se divisa un televisor en funcionamiento, nadie lo mira -de hecho, hay una butaca a su lado, que no frente a él-, ni siquiera hay programación sino que la pantalla está atravesada por bandas de colores onduladas que no cesan de girar, así

55 Con esta abreviatura, $\mathrm{P} 1$, indicamos que se trata del plano $\mathrm{n}^{\mathrm{o}} 1$, y así sucesivamente con el resto de los planos. 
pues, todo ruido. Relacionado con esto último conviene introducir una reflexión de Sánchez-Biosca:

Si hemos hablado de manierismo es porque estos procedimientos formales nos hacen remontarnos a aquel momento de la historia artística que los vio nacer y multiplicarse: el cuadro dentro del cuadro, el relato en el interior del relato, el falso y equívoco punto de vista, el espejo engañoso, la anamorfosis y las aberraciones ópticas... Y todo ello contemplado como si de un juego se tratara, antes de que el barroco tomara al asalto con su trascendencia y decepción estos significantes del vacío. ${ }^{56}$

He aquí el televisor dentro del televisor, una manifestación de la lógica manierista que preside el texto, la lógica del espejismo refractaria -recordémoslo- al principio de realidad.

En el lado opuesto al televisor, a la derecha del cuadro, se ha situado un panel de grandes dimensiones, tal vez una ventana, interior o exterior, donde se reflejan sucesivos destellos de luz que invaden la estancia. Numerosas lámparas en forma de pirámide invertida cuelgan del techo, apuntando en su verticalidad al suelo; una lámpara de pie, alargada, se encuentra en el rellano de la escalera que está al fondo; he aquí la citada profusión de puntos de luz eléctrica, rasgo del estilo Lynch. Una barandilla de asiento ondulado rodea la escalera, en continuidad con las ondulaciones del televisor. Un alto pedestal coronado por un busto femenino marmóreo se halla al pie de la escalera. Todo lo cual, su disposición, permite reconocer el carácter de estancia-escaparate, pues lo que se juega en el texto tiene que ver con una puesta en escena que, en palabras de Bettetini, "corre el riesgo de ser sólo consumada en una situación indiferenciada, de banalidad, de aburrimiento" 57 ; hasta el momento, todo parece agotarse en un ofrecimiento tedioso, por iterativo, para la mirada del espectador.

De pronto, precedida de un estallido de luz, envuelta en una atmósfera centelleante, como salida de la nada, se perfila una figura femenina (Raquel Zimmerman) que desciende la escalera contoneándose al son de la música. Luce un vestido de noche con vuelo, lo que le otorga un aspecto cuneiforme al igual que uno de los objetos decorativos de la estancia, la lámpara del rellano. El texto ha hecho una elección al convocar a ésta y a otras dos modelos más, una elección capitalizadora de Imagos procedentes del mundo de la moda, una elección en lo espectacular que equipara el espectáculo de la moda, el televisivo y el publicitario. En esa línea, he aquí el despliegue de una escenografía seductora en la que ella, la Figura, irrumpe, aislada en ese (su) espacio interior; por cierto que el aislamiento interior de las figuras y la concepción del espacio como proyección de dicho aislamiento, constituye

56 Sánchez-Biosca 1995, op. cit. (nota 42), p. 40.

57 Bettetini 1986, op. cit. (nota 18), p. 196. 
uno de los motivos recurrentes en la pintura de Edward Hopper, autor de referencia para Lynch. En suma, el universo -debiera decirse: el escenario- de la intimidad queda convocado en el texto, la intimidad de esa particular sala de estar exhibida, mostrada ante la mirada pública, al igual que el cuerpo de la modelo, que al menos en parte queda al descubierto, como quedará también el objeto de su deseo, nada más íntimo y comprometedor. En este sentido debemos entender la progresiva aproximación de la cámara a su rostro en planos sucesivos, de modo que el texto irá satisfaciendo la demanda de transparencia (visual) que ha ido generando en su espectador: que todo sea visible, que nada se resista a mi mirada, a $m i$ deseo, ni siquiera el aire que respira, la esencia que -como finalmente se muestra- ella inhala.

En el siguiente plano, la cámara, en travelling de aproximación, toma a la figura femenina al pie de la escalera. El plano es similar al anterior en lo que respecta a la banda sonora y a la presencia de la luz centelleante que, a modo de flash, invade intermitentemente la estancia; como idéntico es el movimiento ondulatorio de la modelo, orquestado por sus largos y delgados brazos. Ella se desplaza de derecha a izquierda de cuadro, girando la cabeza a un lado y a otro, sin detenerse en nada, como es propio del gesto seductor. Pasa por delante de la estatua marmórea que se halla sobre un pedestal, al pie de la escalera, ambas figuras similares en su distanciamiento y frialdad respecto del observador. Su vestido resulta exageradamente escotado, al igual que resulta extrema su delgadez. Apenas un cuerpo que deambula, o debiéramos decir, todo cuerpo, y en este sentido suscribimos la siguiente consideración de González Requena y Martín Arias:

Si el espectáculo responde a la lógica imaginaria del espejo, si se configura como espejo para el deseo visual del espectador, deberá ser, primordialmente, un espejo antropomórfico. El cuerpo, el cuerpo del otro, y ulteriormente el cuerpo de las cosas, del mundo, se constituye en la materia nuclear de todo espectáculo. Y frente a esos cuerpos que en el espectáculo se exhiben -tanto más cuanto más se vacía la dimensión semántica del discurso, es decir, cuando los actos, los gestos y los personajes, ahuecado todo universo narrativo, se perciben en sí mismos, vaciados de significados, como cuerpos y actos que sólo importan por su capacidad de movilizar el deseo de la mirada-, es, finalmente, la pulsión escópica la que impone su (rechazo de toda) ley.58

Recuperando la cuestión referida de la estética manierista, he aquí un cuerpo que responde al modelo longilíneo, el cual ya había estado en auge durante el período gótico, por supuesto el manierismo, y más tarde, a partir de la segunda mitad del siglo XIX, en el decadentismo y el arte prerrafaélico ${ }^{59}$, siendo entonces, como ahora, una expresión del rechazo a la carnalidad, a la materia-Corazón Vítreo, es

58 González Requena, Martín Arias 1994, op. cit. (nota 44), p. 9.

59 Bettetini, Fumagalli 2001, op. cit. (nota 28), pp. 119-120. 
el título del tema musical de referencia en el texto-, y de manera no exenta de sufrimiento, pues hay en estas figuras cierto nihilismo: figuras aisladas, en trance permanente, evidencia de su avocación al autoaniquilamiento. Además de lo cual, son figuras poseedoras de un estatuto ambiguo, mezcla o conjunción de identidades sexuales, figuras de la no diferencia, algo que definió, por su parte, a esa Figura-Imagen primordial de la que da cuenta el psicoanálisis, coprotagonista de un encuentro en el que las diferencias no han sido instauradas todavía. En el texto que nos ocupa el cuerpo, ese cuerpo sin materia toma la imagen, irrumpe literalmente y, participando de la dinámica de cierto flujo, deambula por un espacio artificioso, atestado de apariencias cautivantes; el cuerpo participa, así, de una inercia, un nihilismo que apunta hacia la muerte -pues se entrega en cuerpo y alma-por inhalación de... una fragancia extática. He aquí un cuerpo imaginarizado en su relación con el objeto, cuya propuesta, más allá de todo proyecto enunciador, se agota en la puesta en escena, para la mirada del espectador, de su abandono al elixir, una inercia que, en el extremo, le conducirá a la fusión con el objeto, a su dilución en la fragancia, luego a su desaparición física.

El plano cambia a uno más corto para encuadrar ahora el televisor; reconocemos el sillón contiguo al mismo, encima del cual hay un espejo ovalado en el que se refleja una de las particulares lámparas que cuelgan del techo, al igual que una vidriera artística con motivos geométricos, cromada en tonos dorados. De nuevo la recurrencia en lo cromático: marrones, beiges, oros, blancos; así como en la iluminación mortecina. En el televisor se aprecian con más detalle las ondulaciones que, a modo de aspas, no cesan de girar, mientras la figura femenina, de la que sólo se verá un detalle de su largo vestido cargado de pliegues, atraviesa la estancia, de derecha a izquierda, sin detenerse ante ese aparato al que nadie mira, evidencia pues del vaciado de significación que preside el texto y de su funcionamiento al margen de todo proyecto comunicativo.

En el siguiente plano nos hallamos en una estancia diferente a la anterior, si bien en términos cromáticos y de iluminación se aprecia una continuidad con respecto a las imágenes precedentes: los destellos lumínicos han cesado, pero predomina una luz dorada frente a ciertas zonas oscurecidas. En dicha estancia, una segunda modelo (Freja Beha Erichsen) se mueve de idéntico modo al de la primera modelo, al son de la misma música. Su indumentaria es también similar: un vestido largo de noche repleto de pliegues, en tonos marrón y dorado, y un amplio cinturón que muestra su delgadez. Al fondo, cubriendo las paredes, destacan enormes pinturas cuyas figuras, momentáneamente, parecen desprenderse de la pared y cobrar vida, produciéndose de nuevo una pérdida del principio de realidad, he ahí la experiencia de un delirio, lo que vincula a la modelo en trance con el consumo de alucinógenos, en concreto, con la inhalación del perfume. 
En la estancia se aprecia, además, la presencia de otra estatua colocada sobre un pedestal próxima a las pinturas -obsérvese la omnipresencia de objetos artísticos-; junto a otros puntos de luz, hallamos una lámpara de pie similar a aquéllas, de estilo piramidal, que en planos anteriores colgaban del techo -obsérvese la omnipresencia de la luz eléctrica-; y una mesa en cuya superficie acristalada, especular, se encuentra un teléfono que ella, mientras baila, acaba de colgar. Junto a las vistas aéreas de la ciudad, cuya conexión con los espacios interiores no se articula, he aquí otro posible contacto con el exterior - ¿espera a alguien?-, si bien el texto de nuevo no establece una relación clara entre el interior y el exterior, pues en todo caso en la estancia hay sillones que nadie ocupa, al igual que una mesa con un jarrón de flores encima, que define a éste como espacio de fragancias eminentemente femenino, del que está excluida toda diferencia, luego lo masculino.

El plano siguiente (P2) es más corto que el anterior, reproduciendo así una idéntica lógica de planificación y montaje para cada una de las modelos y de sus iterativas acciones, que va desde el encuadre más abierto al más cerrado, en progresiva aproximación de la cámara a la figura. Se realiza un movimiento en torno a la modelo, escrutándola -la cámara acecha y, tras ella, el ojo del espectador-, tomándola en un plano medio que permite observar de cerca el movimiento ondulatorio de sus largos y delgados brazos, y sobre todo el gesto de trance en su rostro, los ojos cerrados, abandonada a una inercia placentera. El baile exhibido frontalmente hacia la cámara, exhibición en la que el texto se agota al margen de toda pretensión enunciativa, esto es, al margen de toda pretensión en el terreno de la significación y del lenguaje, dicho baile-decimos-permite reconocer la explícita puesta en escena del placer en la que cierto yo en soledad, ella con su objeto y su fragancia, participa.

Una tercera modelo (Natasha Poly) -he aquí la presencia del número tres, la cifra simbólica, pues fue cierta tríada la que protagonizó el complejo edípico, si bien en este caso la tercera figura es en todo equivalente a las otras dos, luego el tres se vacía de valor simbólico- aparece en el plano siguiente, más amplio, siguiendo la lógica del montaje, por ser la primera vez que se la encuadra. En ángulo cenital la cámara se aproxima a la modelo quien, recostada sobre un diván, se contonea al igual que las demás al son de la música. El gesto ondulatorio de sus brazos, reiterado por triplicado, constituye sin duda la visualización de una fragancia cargada de sensualidad, causante a su vez de cierta intemperancia, cierto desenfreno gestual absolutamente yoico: ahí, en ese descomedimiento gestual se reconoce la relación pulsional de Yo con $s u$ objeto.

De nuevo la modelo se caracteriza por su delgadez, cuyo atuendo permite reconocer: un traje de noche largo y dorado, con un grueso cinturón que estiliza aún más su figura, atestado de pliegues, de ondulaciones. Una luz dorada contrasta con la penumbra que domina en la estancia, dicha luz, artificial, procede de las paredes, una suerte de vidrieras policromadas. La estancia semeja circular, en su centro el 
diván con la modelo tendida, y a un lado una mesa cargada de objetos, quizá un tocador, pues en ella parece advertirse un espejo de mano circular. Así pues, la circularidad se hace explícita en el spot: espejos ovalados o circulares, espacios circulares, movimientos de cámara que describen un semicírculo y una sucesión de planos que se repiten formando parte de un círculo recurrente, todo lo cual apunta a la instalación del texto en una dimensión imaginaria de la que no hay, ni se desea, salida alguna. He aquí el universo, un tanto claustrofóbico, de Yo y $s u$ objeto, universo placentero, pleno e infranqueable, si bien pulsional, pues en tanto Yo y su objeto acabarán fusionándose, estarán condenados a la aniquilación.

Un plano más corto (P3) muestra a la misma modelo sobre el diván en idéntica actitud de trance, moviéndose de modo compulsivo, la cabeza echada hacia atrás, ajena a la cámara. Reaparece la luz centelleante del principio que abrasa, sobreexpone por un instante el rostro y el cuerpo de ella, una luz abrasiva que hace visible, que emula el impacto del perfume sobre ese cuerpo desprovisto de sujeto, en tanto desprovisto de sujeción alguna.

A través de un fundido encadenado se produce otro cambio de plano, en éste y en los planos sucesivos tiene lugar la manifestación máxima de lo festivo, si bien, como dijera Bettetini 60 , se trata de una fiesta que renuncia a la instancia comunitaria y que, en la misma medida, se agota en la gratificación de una clausura individualista, una fiesta solitaria, próxima a la evasión o al viaje de la sobredosis. De modo fugaz, pues la duración de los planos en adelante será cada vez menor, se nos emplaza en la primera estancia, en presencia de la primera modelo (Raquel), quien será tomada en plano medio contrapicado, angulación que se repite en los tres planos siguientes, evidenciando así que el movimiento de ella -de todas ellas- se exhibe para nosotros, espectadores. La modelo no cesa agitarse, de bailar, de mostrarnos su recurrente movimiento de brazos.

Este plano se encadena con el siguiente, donde la modelo presentada en segundo lugar (Freja), tomada en plano medio contrapicado, continúa su particular danza, sin mirar a nadie ni a nada, únicamente dejándose llevar poseída, ensimismada. Un fundido encadenado da paso a otro plano de las mismas características, en el que la modelo que aparece en tercer lugar (Natasha) hace exactamente lo mismo que quienes la preceden: bailar absorta, diríase enajenada, al son de la música, agitando su cuerpo, sus brazos. Nada parece desear más allá de lo que posee, todo se agota en algo que la embarga y la hace plena, algo que conecta con el destello de luz que ahora inunda el plano, a modo de flash o de pulverización lumínica que cae sobre ella. En suma, en esta sucesión de planos sólo se asiste a la exhibición de un movimiento y de un ensimismamiento ante la cámara, luego todo se resuelve, se extingue y se consume en el plano de la mirada.

60 Bettetini 1986, op. cit. (nota 18), p. 191. 
Por un instante, cuando el anterior plano y el siguiente se encadenan, esta última modelo (Natasha) y la que ha aparecido en segundo lugar (Freja), se funden en una suerte de metamorfoseado, están presentes a la vez compartiendo un mismo cuerpo y espacio. He aquí el problema -lo problemático- de la identidad, ¿quién es quién?, en tanto el texto se instala en un juego de imágenes, de equivalencias, un juego de espejos, un mero espejismo. De hecho, se vuelve a producir un fundido encadenado similar que conduce de nuevo a un plano de la tercera modelo (Natasha), rematando así el metamorfoseado. Se ha abierto el cuadro con respecto a los dos planos anteriores, lo que permite reconocer la estancia en la que antes se hallaba el diván, un extraño lugar decorado con pinturas y enormes lámparas, similares a antorchas que ardieran en el templo de una diosa: he aquí su/s vestal/es. Un espacio cerrado sobre sí mismo, manifestación del viaje interior que propone el texto, uno sin salida, sin fuga, reiterativo y claustrofóbico, pero un interior sin sujeto, luego ahuecado.

A continuación, retorna el plano general aéreo sobre la ciudad, imagen nocturna de un lugar atestado de luces y arterias muy transitadas, una de las cuales se encuentra en el centro del plano, vía de salida del universo interior que el texto ha ido forjando, si bien, una salida imposible, pues el texto no articula ningún mecanismo para tomarla. En todo caso, he ahí el hormiguero luminoso, la gran ciudad, en la (por la) que todo fluye, todo circula, nada cesa o se detiene, al igual que en el espacio interior donde nada cesa y todo fluye, en este sentido el texto vuelve a erradicar las diferencias.

De nuevo, un plano medio largo contrapicado -similar al plano 9- de la primera modelo (Raquel) con su particular danza; todo se mueve dentro -la cámara, la modelo- y fuera - como hemos visto en el plano precedente-, en el interior y en el exterior de este habitáculo. El plano, de corta duración, se funde con otro (P4), un plano medio corto que, como cabía esperar, corresponde a la segunda modelo (Freja), quien se acaricia el rostro mientras baila. Sin embargo, algo ha cambiado con respecto a las imágenes anteriores, pues ahora la imagen ha perdido toda nitidez, coincidiendo con el toqueteo del rostro de la modelo, propio de quien pierde contacto con la realidad. Su rostro borroso parece confundirse con el fondo -fondo y figura se funden-, con las pinturas del fondo, y así se asiste a la pérdida de los límites formales dentro del cuadro - ¿dónde está la figura, qué se exhibe o quién enuncia en el texto? El plano, breve, se encadena con el siguiente, de idénticas características, y nos devuelve un primer plano de la primera modelo (Raquel) en metamorfosis con la modelo anterior (Freja). La proximidad de la cámara y el desenfoque evidencian la experiencia interior de ella(s), sin duda alucinatoria, una suspensión de la consciencia en tanto toda referencia formal ha cesado, cesando también los límites de yo -de ahí que, una vez más, en la sucesión de planos nos preguntemos ¿quién es quién? Y todavía se produce otro fundido con un plano simi- 
lar al anterior, ahora de la tercera modelo (Natasha), tomada en plano medio, desenfocada, alucinando una experiencia interior extática, al igual que las demás.

Este último plano deriva hacia una sucesión por corte de planos más breves todavía que los anteriores, a modo de flashes visuales, segmentados de hecho por cambios de luz, cambios en la intensidad lumínica y, coincidiendo con ello, por redobles de batería: planos en contrapicado que se repiten hasta siete veces y en los que se alterna el mismo detalle del techo con lámparas en forma piramidal, con un primer plano de la tercera modelo (Natasha), hasta acabar con uno de los planos repetidos del techo, invadido poco a poco por una luz blanquecina, intensa, cegadora, que quema la imagen, la sobreexpone, un plano de mayor duración que funde con el siguiente (P5), un plano medio frontal de la primera modelo (Raquel), quien, tras una descarga de flashes lumínicos -las pulverizaciones abrasivas de perfume-, y por primera vez paralizada, se entrega en cuerpo y alma, con los brazos abiertos, a una ráfaga, un aroma que la invade y que ella inhala con intensidad, mientras la cámara se aproxima lentamente.

El plano se encadena con el siguiente, donde la cámara, en posición frontal, avanza hacia la segunda modelo (Freja) hasta tomarla en primer plano -el rostro de Raquel se ha metamorfoseado en el rostro de Freja. La modelo inhala mientras se advierte la densidad de algo gaseoso, dorado, abrasivo, que fluye en (y destruye) la imagen enturbiando su nitidez. Cada uno de estos planos se ha ido aproximando más al rostro embriagado, extasiado, de las modelos, buscando captar la fusión de la fragancia que circula densificando el aire, el rostro que inhala y el ojo del espectador que mira. He aquí lo ofrecido a nuestra mirada: el gesto del trance sin mística, ése que acaece en un espacio psicodélico, que no sagrado, trance vacuo -pues ningún Él, Otro, es interpelado para otorgarle sentido-, este es el templo posmoderno de las vestales de la moda, consumidoras de un perfume de diseño, causa de la alucinación.

El anterior plano se encadena con el siguiente (P6) propiciando otra metamorfosis, el rostro de Freja en el rostro de Natasha, quien en primerísimo primer plano inhala, en calma, con gesto extasiado ese flujo que se intensifica al tiempo que se densifica hasta invadir el plano, borrando por completo el rostro de ella. Pero el flujo continúa, convertido ahora en espiral que acabará en el rostro de otra modelo, Raquel, quien lo aspira. El plano ha cambiado (P7), ella, en primer plano, sostiene un gran frasco de perfume al que mira con veneración, por primera vez su mirada tiene dirección, por primera vez se interesa por (en) algo. El frasco integra en sí mismo los rasgos cromáticos que hemos ido reconociendo a lo largo del spot: marrón oscuro, dorado y un cierto tono ocre, he aquí que, desde el comienzo, se ha desplegado el universo objetual. Y mientras ella sujeta el frasco con delicadeza y devoción, juntos por fin, el plano se funde con el siguiente, ocupado exclusivamente por el objeto. Adviértase que la modelo no es el sujeto empírico que explica o 
introduce el producto de consumo, luego no actúa como sujeto enunciador, sino que ella, ellas se funden con el producto, participando de un estatuto objetual que las ofrece a su vez al consumo visual del espectador. En este último plano, en el más puro estilo publicitario, ocupando el centro del cuadro, en primer plano frontal, surge el objeto -pues todo acaba en él-, el frasco de perfume, al tiempo que en sobreimpresión aparece su nombre y el de la marca, mientras en off, una voz femenina pronuncia: "Gucci by Gucci", su iterativo nombre. Una ráfaga de luz cae sobre el objeto -como anteriormente había caído sobre las modelos-, que se descubre como intensamente dorado, marrón casi ocre y negro. Tras el centelleo de luz, el objeto desparece en fundido a negro, el objeto, principio y fin de todo el universo textual.

\section{Una última cuestión: ¿dónde hallaremos al sujeto de la enunciación?}

He aquí un texto reiterativo, sin otra estructura que el círculo, una repetición por triplicado: tres modelos -que se funden-, tres espacios -que son el mismo-, y un movimiento ascendente en tres pasos en su relación con el objeto, pues primero ellas bailan en ambiente festivo dejándose llevar por no se sabe qué impulso, de inmediato se manifiesta la alucinación, y por último inhalan fusionándose con el perfume, hasta el límite mismo de su disolución, lo que se aprecia en ese tránsito del plano en el que un flujo vertiginoso integrado por infinidad de gotas doradas ha invadido el cuadro, borrando el rostro de la tercera modelo. La oquedad del texto de Lynch se manifiesta en la oquedad del número tres y en la consiguiente evacuación del sujeto de la enunciación, pues en tanto sujeto del inconsciente su cifra habría de ser el tres. Pero se ha convocado el tres precisamente para vaciarlo de toda capacidad limitadora y en tanto tal fundadora de lugares. Este es el tres del mercado, del consumo -tres por uno, o tres en uno-, sostenido por tres figuras equivalentes, iguales entre sí, triple metamorfosis de la Figura, a su vez poseída y en el extremo fundida con su objeto (de deseo). Y así, podría decirse que este texto, en tanto perteneciente al modelo de publicidad dominante, el modelo seductor, sólo moviliza "los valores empíricos que rigen objetivamente su funcionamiento -el dinero, el deseo-, no concede lugar a la dimensión de los valores transcendentes -simbólicos"61, y en esa medida, construye un espectador entregado a la satisfacción de su pulsión escópica, sin encuadre simbólico alguno. No obstante, matizaremos todavía la afirmación de la regencia del deseo, pues éste en sentido estricto no ha podido ser escrito, no ha podido ser enunciado en un entramado de prohibiciones, de acotaciones, no ha podido ser sustraído a lo imaginario y orientado, por la palabra, hacia lo real.

61 González Requena, Martín Arias 1994, op. cit. (nota 44), p. 11. 
Aun cuando el texto se erige como templo del placer, ha excluido el goce, o lo que es lo mismo, una vía sexual hacia el goce, y por ende, la diferencia sexual, la presencia del otro diferente a mí, resistente a mí, que habrá de conducirme a una experiencia material, real, la del goce de los cuerpos. Por tanto, excluido el goce, excluida la relación diferencial, evacuado el sexo y el cuerpo material, queda evacuado lo real, y en esa medida podemos sostener que en el texto publicitario de modelo dominante no hay escritura posible del deseo, está al margen de esa operación fundadora de la que los textos habrán de hacerse depositarios, en virtud de la cual el Lenguaje irrumpe, portador de una prohibición, en plena relación narcisista para desviar, inaugurándolo, el deseo hacia lo real, hacia un encuentro en lo real con el otro, un encuentro gozoso - que no penoso o delirante- en tanto articulado por la palabra. Lo sexual nos enfrenta con cierto grado de violencia: "el sexo, en tanto que algo muy real, está ineludiblemente relacionado con una violencia pulsional, esencialmente humana"62, y en el horizonte de dicha violencia se hallará el encuentro con la muerte, luego la exclusión del enfrentamiento con lo real sexual, excluye también el enfrentamiento con la muerte, eso hace del spot un texto escapista, luego humana y culturalmente inútil.

El texto está al margen del conflicto en términos freudianos, y de uno enormemente productivo, el conflicto entre el principio de realidad -la evidencia de la muerte- y el principio del placer -su negación, el repudio de lo real63; y decimos productivo porque en el texto puede hallarse una postura heroica ante dicho conflicto: querer saber de lo real, enfrentar la mortalidad de $Y o$, su finitud. He aquí que los textos pueden ser espacios de conocimiento, de un saber que interesa al sujeto; en su lugar, este texto ha optado por la puesta en escena de un delirio provocado por el objeto, por su inhalación, literalmente por su interiorización: interiorizar el objeto, en lugar de interiorizar el saber de lo real. No hay, pues, lugar para el sujeto del inconsciente, no ha sido convocado, luego el núcleo de la enunciación, del acto enunciativo, se ha quedado vacío, se ha ahuecado, y en esa medida el texto publicitario se revela como desapasionado -nadie, ningún sujeto (del inconsciente) se roza con el lenguaje para enunciar su pasión-, al tiempo que perverso -en tanto corrosivo con el orden humano, el que instaura la Ley de la que habláramos al inicio-, y por último, culturalmente indeseable, luego prescindible.

62 Martín Arias 2010, op. cit. (nota 2), p. 7.

63 Ibidem, p. 2. 

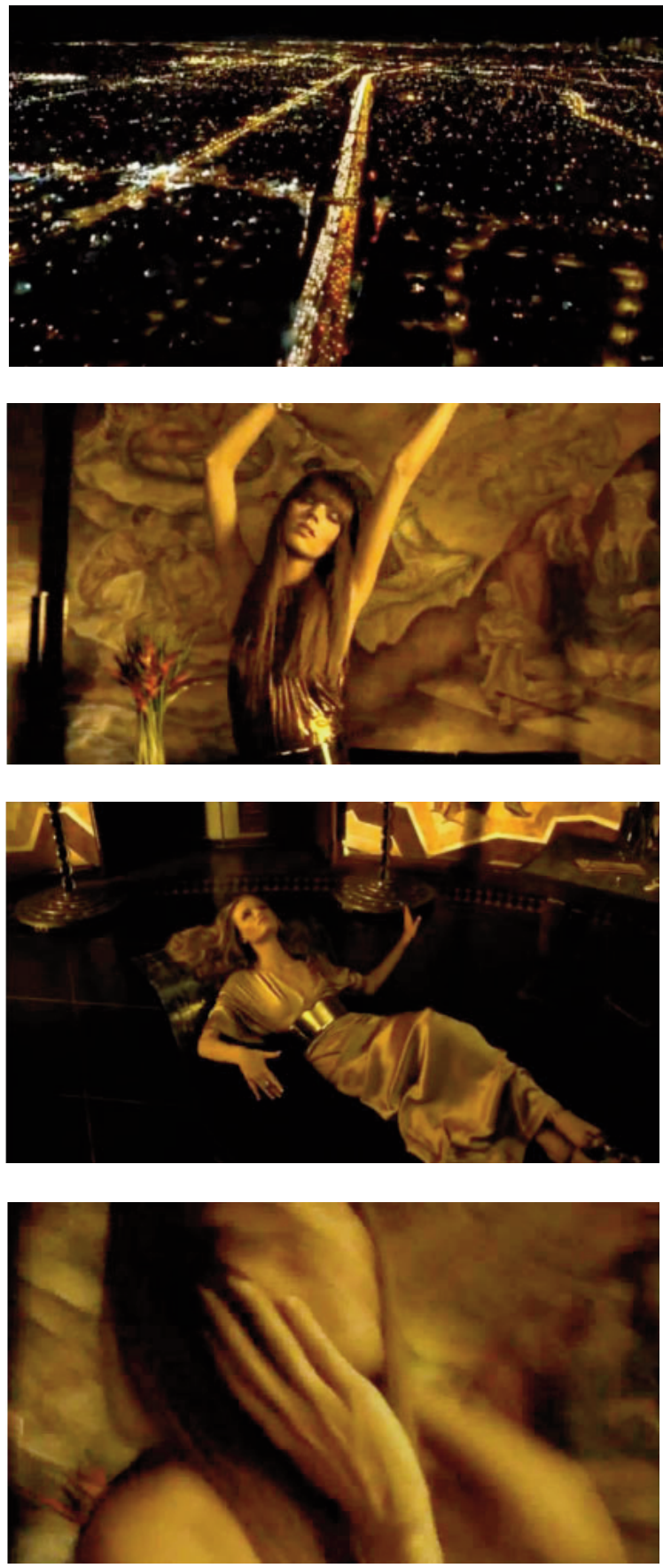

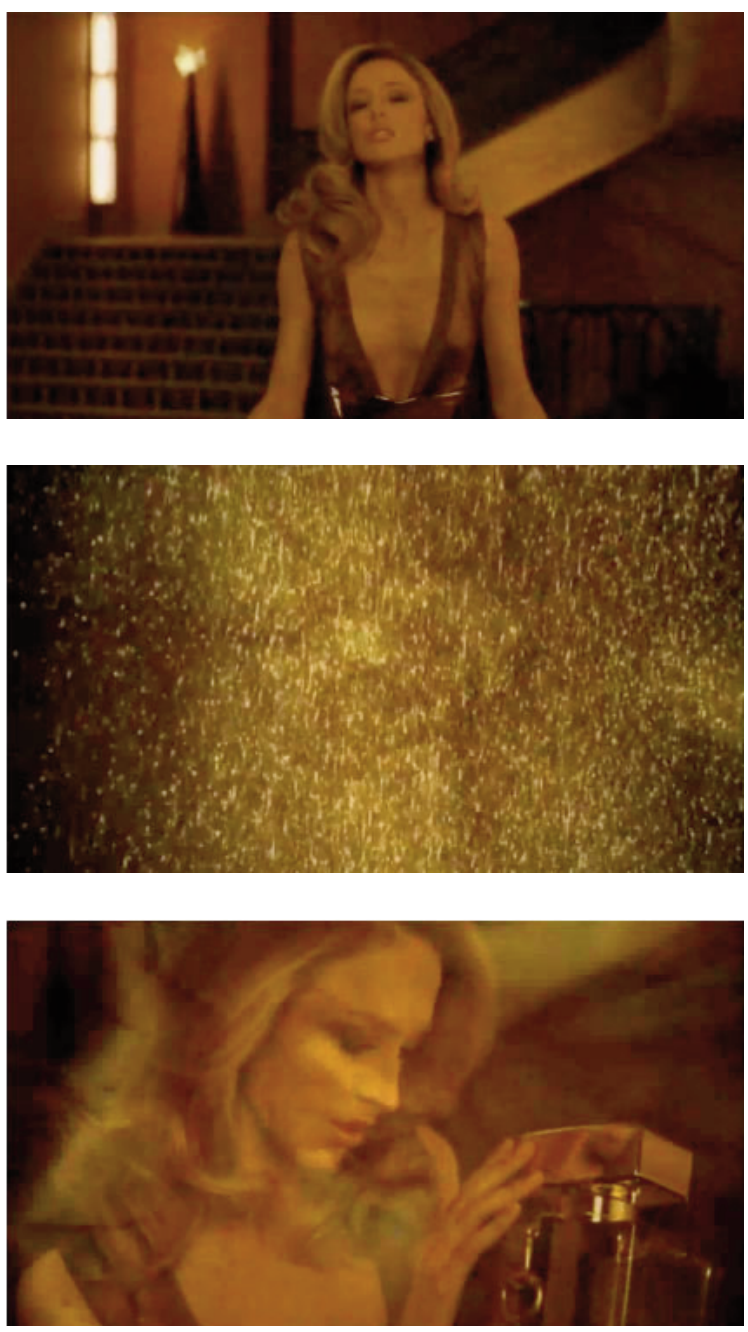